УДК 141.131

ГРИГОРІЙ ХЛЕБНІКОВ

кандидат філософських наук, завідувач відділом філософії Центру гуманітарних науково-інформаційних досліджень IНІОН РАН (Москва, Росія) ORCDI 0000-0001-5410-4807 В'ЯЧЕСЛАВ СТЕПАНОВ кандидат філософських наук, доцент кафедри філософії, сочіально-політичних і правових наук Донбаський державний педагогічний університет (м. Слов'янськ, Украӥна) e-mail: philosophy.kafedra@ukr.net ORCDI0000-0002-2616-1462

ЮЛІЯ ГЛУЩЕНКО студентка педагогічного факультету Донбаський державний педагогічний університет (м. Слов'янськ, Украйна) e-mail:gluschenko.jul@yandex.ua ORCID 0000-0002-7872-3001

\title{
ПЛАТОНІВСЬКА РЕФЛЕКСІЯ ФІЛОСОФІї
}

Стаття присвячена дослідженню проблеми розуміння платонівської техніки розвитку мислення й пайдейї. В роботі визначено, що сучасне використання модусів i технік мислення, які властиві академічним діалогам Платона, пріорітетом мають навчання не стільки основам філософії, а скільки - розвитку та тренуванню власних здібностей філософської рефлексії. Ціллю роботи є розкриття сутніснісних характеристик діалогу як форми визначення істини, зміст яких, за Платоном, виявляється через аналіз феноменального світу. Платонівський підхід зверху-вниз означає, що задовільне розуміння простежуваних феноменів ніколи не може бути виявлено в термінах, а повинно відкриватись в їх не редукованих інтелігібельних принципах. Доведено, що навіть дуже стислий аналіз основних принципів платонізму демонструє в ньому не лише онтологічність й ультимативність божественної першооснови, але й необхідність для людських істот уподібнюватися Богові через Його пізнання. Таким чином, найбільш глибокою спадщиною платонізму є теза про те, що універсум - це системна єдність, що може бути експліційована. Божественне утворює не редуковану пояснюючу (експлікативну) категорію. Для платонізму душа $\epsilon$ принципом життя, а сам універсум є живим і повним живих істот. Схарактеризовані вище принципи платонізму вказують на онтологічний статус людських душ, і на сам процес їх міграції.

Ключові слова: платонізм; розвиток мислення; пайдейя; діалог; божественне; універсум; душа; пізнання; принципи платонізму

\section{Постановка завдання та аналіз останніх публікацій.}

Одне із основних і складних понять філософії, поняття «рефлексія», $є$ спірним та дискусивним i на сьогоднішній день. Як особлива проблема рефлексія стала предметом обговорення ще в давньогрецькій філософії. Давньогрецький мислитель, засновник філософської школи, відомої як Академія Платона, жив у 5-4 ст. до н.е.. Проте і в умовах розвитку сучасного суспільства філософські ідеї Платона, засновника ідеалізму, і на сьогоднішній день актуальні. Значення Платона та його вплив на світову філософію чітко підкреслив англійський філософ і математик Альфред Вайтхед: “Найнадійніша 
характеристика європейської філософії полягає в тому, що вона являє собою лише низку приміток до Платона» (Уайтхед Альфред Норт, 2009).

Метою виховання й розвитку людини філософією античні мислителі вважали його «друге народження»: формування внутрішньої, духовної істоти, яка, очистившись від усього прийдешнього, земного й смертного, здатна пережити не тільки смерть, - момент розділення душі й тіла, - але й вічно існувати в трансцендентному світі.

Якщо учасники діалогу дійсно залучені в опитування, то уявлення про метафізику не повинно бути поверховим і зовнішнім. Як правильно зазначено, не можна сказати, що вони «перемістилися» в метафізику, адже вони ніяк не змогли б переміститися туди: оскільки люди існують, вони вже в метафізиці. Поки людина існує, має місце й філософствування. Те, що називається філософією, суть приведення в дію метафізики, у якій вона повертається до самої себе й своєї безпосередньої задачі.

Тому перехід до різних прошарків і аспектів думки Платона, звичайно, був обумовлений когнітивним каркасом тунелю свідомості співрозмовника, як правило, одного із кращих, якщо не найкращих у групі, тобто визначався екзистенціальною онтологією. Інші студенти повинні були орієнтуватися й шукати свої концептуальні ніші в обговоренні, яке проходило, докладаючи особисті інтелектуальні зусилля для розуміння змісту розмови.

Мета цього дослідження - розкриття сутніснісних характеристик діалогу як форми визначення істини, зміст яких, за Платоном, виявляється через аналіз феноменального світу.

Виклад основного матеріалу. Давня грецька філософія намагалася трансформувати душі як за допомогою різних «духовних вправ», так i веденням філософських дискусій, бо задачею філософії було не передавати «енциклопедичні знання у формі системи» (за словами Адо), а жити пофілософськи. У неоплатонізмі психологія рівносильна містагогії, так що Дельфійська максима «пізнай себе» означає «повернися до першоджерела,

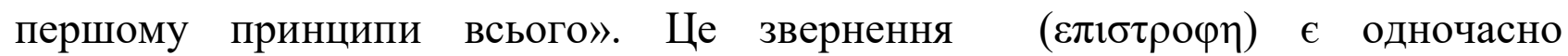
поверненням до самого себе й підйом засобами онтологічних символів, що завершується божественними енергіями (Uzdavinys A., 2004, с.41).

Хоча людські істоти не здатні досягти пізнання богів своїм дискурсивним розумом, згідно з Ямвлихом, філософія на піфагорейський манер є шляхом до мудрості, на якому ми можемо пропонувати не протиріччя, а тверді й незмінні істини, посилені науковим доведенням математики ( $\mu \alpha \theta \varepsilon \mu \alpha \tau \omega v)$ й спогляданням

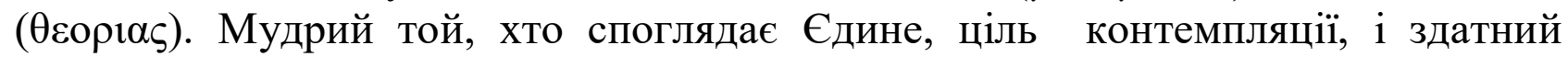
бачити звідси, як 3 оглядової вежі, Бога (який $\epsilon$ над усіма істинами, блаженством, буттям, причинами й початками) і все, що за Ним.

Ціллю платонівської філософії є мудрість і безсмертя, які досягаються

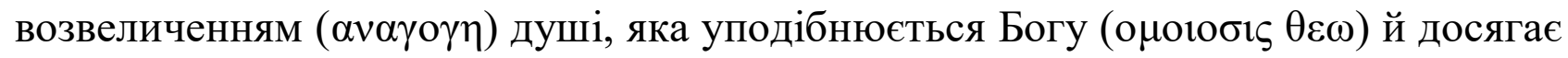
єдності з божеством на рівні поетичних теофаній або самого невимовного Джерела. Тому філософія як раціональний дискурс $\epsilon$ герменевтично розвинутим субститутом давніх ритуалів, які розглядаються як інтегральна 
частина космічних подій i процесів. Самі філософські ігри й пошуки істини можуть бути побачені як особливий і частково індивідуалізований випадок ритуалізованої космогонії, яка $є$ імітацією богів і різновидом божественної служби.

Протягом багатьох років автор справжньої статті у викладанні, зокрема, викладав елементи системи різних технік, які застосовувалися Платоном для маєвтичного пробудження сутнісного мислення й рефреймингу своїх слухачів. Недавно була опублікована французькою мовою цікава стаття Ш. Амьота «Вчитися думати 3 Платоном», яка, на мій погляд, є цінним й оригінальним доповненням того матеріалу. Доцільно використати реферат цієї роботи, у якій Шанталь Амьот сегментує своє дослідження таким чином, щоб у кожному мікророзділі статті експонувати яку-небудь характерну рису, особливість діалектичного методу Платона, переходячи до все глибших шарів думки давньогрецького філософа. Автор указує на глибокий контраст, який існує між шармом і гнучкістю розмов у текстах останнього, - «і укусом у серце душі», який він змушує відчути читача. Платон змушує думку пройти певний шлях, витратити на нього деякий час, щоб за допомогою неї навчитися терпіти й різкі повороти, і пониження польоту, і сум, і навіть роздратування тих, хто хотів би рухатися швидше, набагато стрімкіше (Політик, 286 р.), щоб вона змогла відчути свободу в цьому «божественному блуканні». А потім несподівано вимагати повернення, несподіваної зміни: «Але Сократ, якщо ти говориш правду, - вигукує Каллікл в Горгії, - то все життя людей є догори дригом, а ми, ми всі буцім робимо зворотне тому, що вимагається» (Лосев А.Ф., 1969, с. 199). Це заклик до боротьби за співрозмовника, щоб він повернувся до внутрішніх джерел своєї душі й пробудив у серці бажання жити справедливо й правильно.

Саме в практиці діалогу відбувається це звернення, бо діалог - це, власне, думка, яка все більше набирає вагу й інтенсивність. Розмовляти з іншими - це значить думати 3 іншими. Не для того, щоб «говорити ні про що», або дізнатися, « що кому здається». Нi, випробовуванню піддаємося умовні «ти» $\mathrm{i}$ «я», немає нічого кращого, ніж «я» і «ти», щоб піддати те, що ми говоримо, випробовуванню запитаннями (Протагор, 331 р.). Критерієм діалогу, який веде до істини, є те, що можна вільно запитувати й відповідати, можна змінювати думку, запитуючи себе, чим те або це може бути, щоб змогти дати самому собі на це відповідь, яку потім можна надати іншому. При цьому зовнішнє вираження завжди підтримується тим, що говориться самому собі. На підтвердження цього Амьот наводить наступний фрагмент із діалогу Теетет: «Заклич себе думати про те ж, що і я, - вимагає Сократ у Теетета, - (..) якусь дискусію, яку душа веде сама із собою з приводу речей, які ій прийдеться розглядати (...), або ось, як мені здається, робить душа, коли вона думає: ніщо інше, як веде діалог, запитуючи саму себе й відповідаючи самій собі, стверджуючи й заперечуючи. А коли, роблячи висновок трохи повільніше або, навпаки, прискорюючись до завершення, вона говорить тільки одним голосом, не розподіляючись, то тут ми вважаємо, що така їі думка. (Теетет, 190 р.). I Теетет із цим погодився. 
Проте, зауважує автор, запитувати себе - це для душі, яка мислить,значить жити двояко: вона саму себе запитує й вона намагається дати самій собі відповідь. Вона в чомусь невпевнена, і там, де починає з'являтися простір від себе й до себе, і народжується рефлексія. Усе, що розділяє душу, стає перепоною миттєвому судженню і $є$ гарним приводом для виникнення думки.

Неясність, яка сприймається, змінюється інтелектуальним непорозумінням, коли душа задає собі питання, що таке число: воно одне чи багато. Або одночасно те й інше? Таке протиріччя стимулює мислення.

Платон далі знаходить спосіб вести дискусію так, щоб той, хто говорить, ніколи не був рівним із іншим. Для цього він стверджує, що суперечка повинна вести логос, тобто те, з чим можуть погодитися обидва співрозмовники в ім'я розуму, а зовсім не бажання перемоги в суперечці: «Ти думаєш, - запитує Сократ у Харміде, - що коли я засипаю тебе запитаннями, то роблю це для будь-чого іншого, ніж ради того, що змушує мене досліджувати самого себе, тобто страх обманути себе, думаючи, що я знаю те, чого не знаю?», (Лосев А.Ф., 1969, с.201). І це ж має місце в дискусії, яку людина веде із собою, коли думає, бо ії думка опосередковується тим міркуванням, яке ніхто інший в ньому або поза ним міг би висунути в якості заперечення.

Перше, преамбула будь - якої істинної думки - це необхідність дослухатися логосу, слухаючи іншого, дозволити досліджувати себе його запитаннями, приймати, - не припиняючи дебатів і не відходячи від теми, ситуацію, коли ти суперечиш самому собі. Саме про це говорить фігура Сократа. Сократівська іронія дає можливість звільнитися від найбільшого невігластва - думати, нібито знаєш, чого не знаєш, наказує думати, перш ніж відповідально діяти. Бо маєвтика - повіальне мистецтво для розуму грунтується на переконанні: істина існує і в інтересах всіх людей, щоб вона проявилася. Саме цим оживляється платонівський діалог, який відмовляється обманювати й обманюватися, викриваючи оману, показуючи, яким чином вони конструюються, відмовляючись залишатися серед видимого, горезвісних «тіней» печери, які приймаються за істину (Держава, VII), - i все це через посередництво питань і відповідей, але без будь-якого полемічного пафосу. Тут у грі , зазначає автор, життя думки.

I саме цей атитюд відповідальності i це переконання змушують нас відмовитися від гри 3 «репрезентаціями», які не мають ніякого впливу на наш спосіб життя, так як у софістів, які розважаються тим, що шукають красу мови, яка дивує молодь (Софіст, 234 р). Вони грають з вимовою, акцентами, змістом висловлювань, але ніколи не доходять до самого акту думки, живуть на епідермі своєї душі, поступаючись насиллю своїх пристрастей.

Більш того, мова не йде тільки про демонстрацію іншому неправдивої або істинної концепції реальності. що було б лише риторикою, а не істинною думкою. Відвойований простір використовується для роздумів, не припиняючи ні на мить роздумів проте, щоб думати в істині.

Проте, коли прийняті умови чесних дебатів, коли учасники погодилися очиститися й звільнитися від свого неправдивого знання й брехні, складнощі 
все ще залишаються: як здійснити вибір серед багатьох точок зору? Бо, розшукуючи істину, не можна їх просто нагромаджувати рядами, одну біля іншої. Сдиний спосіб уникнути анархії, у якій зникне взаєморозуміння (через ігри в різне значення слів) - увесь час скорочувати суперечку і навіть зупинити дискусію, щоб прийти до загально прийнятої дефініції й перевірити ще раз їі обгрунтованість. У Софісті говориться: «...важливо завжди і в будь-якому дослідженні погодитися 3 дефініцією суті самої речі, використовуючи розум, який ऑii визначає, ніж погодитися відносно імені, не турбуючись про визначення», (Uzdavinys A., 2004, с. 202-203). Таким чином, думати - значить намагатися схопити через різноманіття аспектів будь-якої речі те, що може бути зрозуміле всім, а потім скорочувати це розуміння навколо утвореного поняття єдності, яке й буде їх логосом. Це означає не починати з дефініції, а займатися їі пошуками.

Так суперечка стає філософською, бо правильне визначення повинно відсилати до того, чим по правді $є$ ця річ, до їі «усії», тобто тому, що вона є, тому способу буття, з приводу якого ставляться запитання й отримуються відповіді, що намагаються зрозуміти, розшукуючи іiі модус розуміння, який виявляється в тому, що Платон називає формою. Цей спосіб буття «завжди залишається одним і тим же» (Федон, 78 р.), не схильним до становлення, він абсолютно «у собі самому», у значенні, яке не залежить від чуттєвого, але це останнє партиципує йому, щоб мати будь - яке буття. Тільки погляд думки може його схопити й побачити каузальність взаємодії в цьому феноменальному світі. Тому його й називають «ейдосом» та «ідеєю» (від грецького «дивитися, бачити»). Ця ідея є тим початком, принципом, який дає розуміння того, що намагаються мислити, і саме його зміст можна вже виразити. I хоча він відкривається в усі часи, сам є атемпоральним, має значення для всіх й у всі часи. Так думка відкриває універсальне, яке збирає й ілюмінує, є найбільш реальним у своїй стабільності, ніж те, що дають людині іiі чуттєві сприйняття. Але перш ніж насолоджуватися ними, думка може розмірковувати над різними модусами, які їй зустрічаються в справі, відповідно до сфер, де вона діє (Лосев А.Ф., 1969, с.203).

Тут діалог поширюється і йде різними стежками, якими рухається думка i які, у свою чергу, визначають типи пізнання. 3 чуттєвими образами речей, які ми сприймаємо, вона може лише будувати припущення, може отримати переконання, але вони ще не будуть обгрунтованими. Відштовхуючись від цих образів, душа, за Платоном, переходить від чуттєвого до інтелігібельного, де проявляє себе в математичній формі. Вона виявляється посередником між ними й робить раціональні висновки 3 гіпотез, які сама ж створює. Проте за цими першими положеннями, на зразок математичних пропозицій, думка рухається у свою власну область, туди, де діанойя, тобто думка, - уточнює автор, - яка йде своїм власним шляхом, відкриває для себе діалектику, науку наук, яка одна тільки здатна досягти передчасного. Там вона стикається з буттям й істиною, не припиняючи їх "досліджувати", але вже маючи справу виключно з самою собою, займаючись тільки своєю вільною сферою, продукуючи безліч аспектів і 
нюансів в інтелігібельному якого-небудь питання й знаходячи розшукуване визначення, яке влаштовує їх всіх. Погляд рухається за цими емерджируючими атемпоральними формами, не схильними до зміни, при цьому кожні одні й ті ж швидше, чим одні й ті ж. Тому й можна говорити про інтелігібельне споглядання. Але це вимагає безперестанної освіти, на яку повинні погодитися ті, хто по-філософськи обдарований. Ті нещасні, які прекрасно обдаровані природою, але не отримали подібної освіти, будуть гіршими з усіх, оскільки око їх душі буде занурено у бруд. Але такі сумні умови людського існування найчастіше зустрічаються, якщо тільки їх не звільняють від пут неуцтва і тим самим не змінять. Люди залишаються в полоні своїх ілюзій (Держава, VII 514). На підтвердження наводиться відомий міф про печеру, у якій люди-полонені не можуть навіть перевести свій погляд в мороці, що не знає світу Сонця, i гніваються на тих, хто змушує їх повернути голову і йти до світла, під яким розуміється істинне мислення на шляху пізнання істини (Лосев А.Ф., 1969, с. 204). Для тих, що прагнуть ідей, потрібна ще одна пурифікація: ідеї не можна уявляти собі у вигляді речей,які сприймаються чуттєво, даючи їм уявне існування в іншому часі й іншому просторі. Ідея вогню - не вогонь. Ідея - не річ. Подібна реіфікація форм зробила б 3 них немислимі умови інтелігібельності, що й показує ментальна техніка Парменіда.

Відтепер думка вчиться жити вільно і ясно. Перед усіма питаннями, кожне 3 яких досліджується в усіх відношеннях і сферах, вона й застосовує своє дослідження: вона аналізує й прагне синтезувати їх у понятті, групуючи в єдність усю безліч цих мислеоформлюючих рис (Лосев А.Ф., 1969, с. 205).

Насправді неможливо прийти до розуміння інакше, ніж маючи образ цілого, побудований i впорядкований згідно з природними артикуляціями. Істина, імплікована в образ цілого, залежить від розуміння дистинкцій i, таким чином, від аналізу й розділень. Одна тільки артикуляція i, отже, дистинкція багато чого в єдиному, істинно детермінує об'єкт думки. Звідси й виникає любов Платона до цих розділень, стосунків родів і видів цим підрозділам, яким вдається упіймати навіть найбільш невловиме, що ховається в подібності, софізмі. Дещо перебільшуючи, Платон стисло виражає це таким чином: "Об'єднаймо все те, що пов'язано з його ім'ям, з початку до кінця.... техніка імітації, здатність провокувати протиріччя, іронія в техніці зовнішній стосунків, здатність продукувати ілюзії, але не божественні, а людські, здійснювати чудеса в дискурсі, - такі, як мені здається, родовід, як говориться, софіста" (Софіст, 268 р). Тут, переходячи від частини до частини, думку синтезує те, що вона спочатку розділяла, аналізуючи (Лосев А.Ф., 1969, с. 205).

Але вимагається ще й правильно робити висновок, що неможливо, якщо тільки грати всіма цими формами, не визнаючи, що ціле буття вимагає стабільної єдності, щоб бути зрозумілим. Вимагається навіть відшукати міру реальним речам, які б спрямовувалися до буття й фіксувалися в становленні, докладаючи зусиль до того, що саме по собі безмежне (наприклад, задоволення) й прийдешнє (Лосев А.Ф., 1969, с. 205-206). 
Але якого різновиду ця міра? Звичайно, не чисто кількісна, прикладена неважливо до чого, а міра, адаптована й диверсифікована відповідно до типів проблем i ситуацій. У будь-кому випадку вимагається дати артикульовану структуру того, про що йде мова, але не як готове ціле, а як процес пошуку. Тут немає готового методу, якому можна слідувати, швидше, це вказівка на певний ритм, витонченість думки, винахідливість, що увесь час поновлюється.

Для досягнення цього такту, цієї правдивості думки,цього тренування в мисленні усі засоби хороші. Думку можна коригувати багатьма способами: не слід поспішати 3 визначеннями, стаючи жертвою упереджень, не можна все змішувати й розміщувати на одну площину, необхідно схоплювати ієрархію логічних артикуляцій і не думати, що будь-яке слово обов'язково посилає до якої-небудь сутності. Треба також використовувати міфи, щоб розглядати нові питання та відповіді й не слідувати механічно якому-небудь методу, будь то хоч розділення. Потрібно наводити як приклад парадигми, щоб уловити непомітні подібності, на зразок мистецтва ткацтва в Політиці, щоб краще зрозуміти політичну дію. Усе добре для живої думки, яка вчиться аналізувати й синтезувати, використовуючи зовсім не один і той же образ, а саме різні предмети (Лосев А.Ф., 1969, с. 206).

Який же секрет подібного динамізму? I хто робить так, щоб думка філософа стала "окриленою" (Федр, 249 р.)? Саме любов іiі підтримує в зусиллі й у стражданнях, "ерос", який не може бути описаний i оточений ніяким визначенням. Розумне пристрасне бажання, любов - і є філософія, позбавлена всього, і завжди є в пошуку заповнити те, чого ій не вистачає (Бенкет, 203 р.), i вона не задовольняється однією різноманітністю, а прагне до єднання й має силу поєднувати відмінності в пориві, які змушують іiі піднімати вгору щось вагоме й важке. Філософія - це звільнена любов, ерос, що знайшов свої крила (Лосев А.Ф., 1969, с. 206-207).

Душа у своєму пориві піднімається до джерела всякого розуміння, усього досягнення й буття, до цього Одного по той бік будь-якої єдності, цього Блага, яке дає доцільну основу розуміння цього існування, цієї Краси, яка сяє й примушує народитися найкраще серед усіх безумств. Джерело, яке є самою субстанцією думки, воно примушує народитися в душі пристрасті спогадів усіх цих інтелігібельних реальностей, яку вона має як ностальгію. Саме про це говорить міф про анамнесис (Федр, 248 р.).

Насправді, вчитися, чи не означає це згадувати те, що душа колись споглядала? Який же тенор, лейтмотив цього міфу? Це особлива манера говорити про те, що не можна налити істину в душі ззовні, необхідно, щоб вона віднайшла їі як деяке особисте благо, розшукуючи в собі самій, щоб зробити іiі своєю. Але це і та туга, яку душа відчуває по передчасному й інтелігібельному, i iï завзяття їх знайти. Поза сумнівом, Платон говорить про вигнання, у Федре, він розповідає про перехід душі в тіло, але чи не для того, щоб показати, як душа у своїх спогадах здатна стати єдиною, охоплюючи у своєму русі всі ці відмінності, щоб вибірково повернути їх до Одного? Щоб показати, людина відтепер композит - також має можливість подолати поділ, єднаючи цей 
композит? І через цей рух до Одного його душа рідниться з душею богів (Лосев A.Ф., 1969, с. 207).

Пізнавати за допомогою цього міфу такий розподіл - означає бути залученим до подвійної бесіди. Передусім, визнати "правильною мірою" обмеження нашого мислення, яке ніколи не може охопити це Джерело: "Здається, що речі, які пізнаються, не лише можуть пізнаватися завдяки благу, але і їх буття, і сутність даються їм від нього, хоча саме благо не сутність, а за межами сутності, перевершуючи іiі гідністю й силою". - Тут Глаукон вигукнув: "Присягаюся Аполлоном, яке дивовижне перевершення" (Держава, VI, 509 р.).

Це робить неможливим замикання мислення на догматичному змісті. Проте усередині цих меж буття стає гідним безсмертя: "Чи не відчуваєш ти,сказала Діотіма, - що тільки саме у цей момент, коли він побачить Красу за допомогою того, що іiі робить видимою, він буде в змозі створити не лише образи істини, бо не образу він торкається, а справжні реальності, бо він торкається до істини. Але якщо він народить справжню доброчесність і вигодує iii, хіба не гідний він любові богів? I якщо серед усіх людей $є$ хоч би один, гідний безсмертя, то чи не він це? " (Бенкет, 212 р.).

Висновки. При цьому автором цієї статті у викладанні зверталася увага i на інтегральне розуміння усього вчення Платона, що реконструюється за сумою концепцій, які містяться в різних діалогах. Платон підходить до аналізу феноменального світу на основі принципів, отриманих при вивченні інтелігібельного ("зверху - вниз"). Підхід зверху - вниз означає, що задовільне розуміння спостережуваних феноменів ніколи не може бути знайдено в термінах, наприклад, їхніх фізичних частин, а повинно бути відкрито в їх не редукованих, інтелігібельних принципах.

По-перше, універсум є системною єдністю. Ця теза - найбільш глибока спадщина платонізму, отримана від досократиків, які розуміли цю єдність світу в тому сенсі, що конституанти закони останнього, згідно 3 якими він функціонує, реальної нтелігібельно пов'язані один з одним; завдяки цій єдності й можливе систематичне пізнання світу. Тому окремі доктрини метафізики, эпістемології, етики і т.д. ультимативно співвідносяться один 3 одним усередині цієї системи. Більше того, вони неподільні, оскільки принципи, які дають можливість формулювати концепції в одній області, ідентичні 3 тими, які дозволяють це в іншій.

По-друге, ця систематична єдність є ієрархією, яка може бути эксплиційована. Платонічний образ світу (ключ до всієї системи) бачить в універсумі ієрархію, яка повинна бути зрозуміла зверху вниз на основі, головним чином, двох критеріїв: а) просте передує складному; і б) інтелігібельне передує чуттєвому. Передування в обох випадках не темпоральне, а онтологічне й концептуальне. Тим самим, розуміння складного i чуттєво, яке сприймається, залежить від інтерпретації простого й інтелігібельного, оскільки останнє є поясненням першим, а ультимативним пояснюючим принципом в універсумі повинно бути просте, що не кваліфікується. У силу цього платонізм є в певному значенні редукцивізмом, 
але інакше, ніж філософія, що йде "від низу до верху"; він дедуктивний концептуально, але не матеріально. Чи може і до якої міри просте, що не кваліфікується, бути інтелігібельним або ж воно в якомусь сенсі трансцендує інтелігібельність є глибоким питанням в самому платонізмі.

По-третє, божественне утворює нередуковану пояснюючу (експлікативну) категорію. Істотною частиною системної ієрархї̈ $є$ Бог, наведений передусім для пояснення чуттєвого світу або світу становлення. Платонізм фокусується на ідеї, що божественне має всеосяжну силу пояснення - немає нічого, що воно б не могло пояснити. Таким чином, онтологія і теологія стають нероздільними. Платонівське поняття божества включає також персональний елемент, який неможливо усунути і який часто ослабляється із-за різноманітних зусиль використати як інтелігібельне, так i просте разом із божественним для пояснення усього іншого. Особовий елемент божественного агента, що залишається, у цьому транзитивному порядку утримується, зважаючи на базову платонічну тезу й звернення до людини "стати подібним до Бога". Благовоління й провидіння вважаються істотними рисами божества, особливо коли воно розглядається в "деперсоналізованому" варіанті.

По-четверте, психологічне конституює нередуковану пояснюючу категорію. Для платонізму сам універсум є живим і повним живих істот, а душа $\epsilon$ принципом життя. При цьому життя не вважається эпіфеноменом або чимось, що розташовано на неживому. Навпаки, саме душа відіграє унікальну експлікативну роль у систематичній ієрархіі; незважаючи на те, що вона $\epsilon$ базовим початком пояснення, душі індивідів адаптовані й субординовані в загальній ієрархії. Однією з центральних тем платонізму було відношення між інтелектом, мисленням й інтелігібельним, з одного боку, і душею - $з$ іншого. Як фізичне вважалося таким, що не зводиться до матерії, так й інтелігібельне не редукувалося до психічного. При цьому інтелектуальне не було ні аспектом, ні дериватом психічного, а передувало йому.

По-п'яте, особистості належать систематичній ієрархії й особисте щастя полягає в досягненні втраченої в ній позиції. Усі платоніки вважали, що в деякому розумінні особа і $є$ душею, яка безсмертна. Оскільки, можливо, найбільш важливою рисою божества було безсмертя, метою втіленого індивідуального існування було "стати подібним до Бога". Але оскільки не можна прагнути стати тим, чим ти вже є, то це завдання знаходиться між двома полярними й загальними грецькими концептами: природи або того, "що є", i тим, "що повинно бути". Таким чином, нормативне заткане в те, що об'єктивне реальне, а людей закликають стати тими, ким вони "реально", воістину або ідеально є. Можна сказати, що першим принципом платонівської етики і $\epsilon$ необхідність "стати подібним до Бога".

I це - мета, яку цілком можна досягти Як показує Ф. Шлезак, у Платона існує можливість двох протилежних інтерпретацій концепції філософії у Платона: філософія як нескінченне прагнення - проти філософії, здатної досягти мети в надбанні знання (Szlezak T.A., 2003, с.138-139). На користь останнього Шлезак наводить (H.G.Liddell and R.Scott, 1996, с. 532), де 
говориться про "відпочинок від шляху й кінець подорожі". Сократ, крім того, говорить про "достатнє бачення блага" (H.G.Liddell and R.Scott, 1996, с. 519), й атрибутує душі силу знаходитися в іï спогляданні, а також досліджувати й бачити, як це відбувається (H.G.Liddell and R.Scott, 1996, с. 516).

По-шосте, епістемологічний порядок включено в метафізичний. Когнітивні модуси ієрархічно градуйовані відповідно до ієрархічних рівнів об'єктивної реальності, так що вищий модус когнітивності відповідає першим експлікативним принципам. Усі когнітивні модуси, що включають чуттєві сприйняття й потребують їх як умову свого функціонування, $\epsilon$ нижчими порівняно з найвищим модусом. Те, що особистості можуть бути суб'єктами як найвищого когнітивного модусу, так і найнижчих, вказує на двозначність або конфлікт в особистості між пристрастями втіленої людської істоти й бажаннями ідеального деметеріалізованого когнітивного агента. Цей конфлікт рефлектується, наприклад, в різних трактатах споглядального й практичного (Gerson L.P., 2005, с. 253-276). Це, на думку Джерсона, основні риси платонізму. Інші, включаючи теорію ідей, є дерівативними (Gerson L.P., 2005, с. 262-264).

Отже, сам платонізм зберіг реальні досягнення античної філософії і забезпечив сучасникам фундамент для подальшого розвитку більшості сучасних наук. Ідея освіти, яка виступає як регулятивний принцип всієї платонівської філософії, займає абсолютно особливе місце у вченні цього давньогрецького філософа. Платон, як i його вчитель, був педагогомкерівником, і хоча про його діяльність в Академії відомо дуже мало, тексти платонівського корпусу використовувалися в освітньому процесі i, відповідно, можуть застосовуватися в цій якості в наші часи як інструменти, призначені для досягнення освітньої мети.

\section{СПИСОК ВИКОРИСТАНИХ ДЖЕРЕЛ}

Уайтхед Альфред Норт. Приключения идей.Перевод с англ. Л.Б. Тумановой ; примеч. С. С. Неретиной. М. : ИФРАН, 2009. - 383 c. https://platona.net/ load/knigi po filosofii /filosofija poznanija/uajtkhed_a prikljuchenija idej/45-1-0-3544

Nails D. Agora, Academy, and the Conduct of Philosophy / D.Nails.- Dordrecht : Kluwer Academic Publishers, 1995. - $264 \mathrm{pp}$.

Лосев А.Ф. История античной эстетики; в 8 т. /А.Ф. Лосев. - М.: Искусство, 1966. - Т.2; Софисты. Сократ. Платон. - 1969. - 816 с.

Gerson L.P. What is platonism? // J. of the history of philosophy. - Baltimore, 2005. - Vol.43, N 3. - P.253-276.

Szlezak T.A. Die Idee des Guten in PlatonsPoliteia: Beobachtungenzu den mittlerenBüchern. SanktAugustin, 2003. - VIII, $160 \mathrm{~S}$.

Uzdavinys A. Divine rites and philosophy in neoplatonism // ActaOrientaliaVilnensia. - Vilniaus, 2004. - P.39-53.

Liddell H.G. and R.Scott. A Greek-English Lexicon / [rev. by St. Jones].- New York : Oxford University Press Inc. 1996. - 2042 pp. 
ГРИГОРИЙ ХЛЕБНИКОВ

кандидат философских наук, заведующий отделом философии Центра гуманитарных научно-информачионных исследований ИНИОН РАН

(2. Москва, Россия)

ORCDI 0000-0001-5410-4807

ВЯЧЕСЛАВ СТЕПАНОВ

кандидат философских наук, дочент, кафедры философии, сочиально-политических и правовых наук Донбасский государственный педагогический университет

(2. Славянск, Украина) e-mail: philosophy.kafedra@ukr.net ORCDI0000-0002-2616-1462

ЮЛИЯ ГЛУЩЕНКО

студентка педагогического факультета Донбасский государственный педагогический университет

(2. Славянск, Украина) e-mail:gluschenko.jul@yandex.ua ORCID 0000-0002-7872-3001

\section{ПЛАТОНОВСКАЯ РЕФЛЕКСИЯ ФИЛОСОФИИ}

Статья посвячена исследованию проблемы понимания платоновской техники развития мышления и пайдейи. В работе определено, что современное использование модусов и техник мышления, которые свойственны академическим диалогам Платона, пріоритетом имеют нестолько обучение основам философии, а сколько - развитие и тренировку собственных способностей философской рефлексии. Целью работы является раскрытие сущностных характеристик диалога как формы определения истины, содержание которых, по Платону, проявляется через анализ феноменального мира. Платоновский поход сверху вниз означает, что удовлетворительное понимание прослеживаемых феноменов никогда не может бать обнаружено в сроках, а долино открываться в их нередуциррованых интеллигибельных принципах. Доказано, что даже очень краткий аналіз основних принципов платонизма демонстрирует в нем не только онтологичность и ультимативность божественной первоосновы, но и необходимость для человеческих существ уподобляться Богу через Егопознание. Таким образом, наиболее глибоким наследием платонизма является тезис о том, что универсум - это системное единство, которое может бать эксплицированно. Божественное образует нередуцированную объясняющую (экспликативную) категорию. Для платонизма душа есть принципом жизни, а сам универсум является живым и полным живих существ. Охарактеризованные выше принципы платонизма указывают на онтологический статус человеческих душ, и на сам процесс их миграции.

Ключевые слова: платонизм; развитие мышления; пайдейя; диалог; божественное; универсам; душа; познание; принципы платонизма 
HRYHORII KHLIEBNIKOV

Phd in Philosophy, Head of the Department of philosophy center for Humanities Scientific and Information Studies INION Sciences

(Moscow, Russia)

ORCDI 0000-0001-5410-4807

VIACHESLAV STEPANOV

PhD in Philosophy, Associate Professor of the Department of Philosophy,

Socio-Political and Legal Sciences,

SHEI "Donbas State Pedagogical University" (Sloviansk, Ukraine) e-mail: philosophy.kafedra@ukr.net ORCDI0000-0002-2616-1462

YULIIA HLUSHCHENKO

Student of the Pedagogical Faculty, SHEI "Donbas State Pedagogical University" (Sloviansk, Ukraine) e-mail:gluschenko.jul@yandex.ua ORCID0000-0002-7872-3001

\section{PLATONIC REFLECTION OF PHOLOSOPHY}

The article is devoted to the study of the problem of understanding the Platonic technology of the development of thinking and pseudoeias through the prism of teaching to students-philosophers and theologians. It is determined that the modern use of modus and technique of thinking, which are inherent in the Academy\&apos; s paiadios and the dialogues of Plato, have priority not only to the basics of philosophy, but more to development and the training of their own abilities of independent reflection. The dialogue is construed as an opinion that leads to the truth. The plate approaches to the analysis of the phenomenal world, where the approach from the top to the bottom means that for. The explicit understanding of traced phenomena can never be found in terms, but should be discovered in their unidentified, intellectual principles. It has been shown that even a very concise analysis of the basic principles of Platonism shows in it not only the ontological and ultimatum of the divine primordial but also the need for human beings to be likened to God and His knowledge. In the concept of paydey, the key attributes of thinking, understood as a practical characteristic of human existence, are concentrated. Paydey at Plato is at the same time a leak, and a way, and for the purpose of realizing the thought inexhaustible in its potential, dominant over the real order of things. It is noted that the universe is a system unity. This thesis is the most profound legacy of Platonism, and, due to this unity, systematic knowledge of the world is possible. Consequently, the idea of education, which acts as a regulative principle of all Platonic philosophy, occupies an absolutely special place in the teachings of this ancient Greek philosopher. Plato, like his teacher, was a teacher-manager, and although his knowledge of the Academy was very little known, the texts of the Plato\&apos; s Corps were used in the educational process and, accordingly, can be used in this capacity in our time as instruments designed to achieve educational goals . To date, Platonism has preserved the real achievements of ancient philosophy and provided contemporary foundation for the further development of most modern sciences.

Key words: Platonism; development of thinking; Paideia; dialogue; divine; Universum; soul; cognition; principles of Platonism

\section{REFERENCES}

Uaitkhed Alfred Nort. (2009). Prykliuchenyia ydei.Perevod s anhl. L.B. Tumanovoi; prymech. S. S. Neretynoi. M.: YFRAN. 383 s. https://platona.net/ load/knigi_po_filosofii /filosofija poznanija/uajtkhed_a_prikljuchenija_idej/45-1-0-3544 
Nails D. (1995). Agora, Academy, and the Conduct of Philosophy / D.Nails.- Dordrecht : Kluwer Academic Publishers. 264 pp.

Losev A.F.(1969).Ystoryia antychnoi эstetyky; v 8 t. A.F. Losev. - M.: Yskusstvo. - T.2; Sofysty. Sokrat. Platon. $816 \mathrm{~s}$.

Gerson L.P. (2005) .What is platonism? J. of the history of philosophy. Baltimore. Vol.43, N 3. P.253-276.

Szlezak T.A. (2003). Die Idee des Guten in PlatonsPoliteia: Beobachtungenzu den mittlerenBüchern. - SanktAugustin. - VIII, $160 \mathrm{~S}$.

Uzdavinys A. (2004). Divine rites and philosophy in neoplatonism. ActaOrientaliaVilnensia. Vilniaus. - P.39-53.

Liddell H.G. and R.Scott.(1996). A Greek-English Lexicon [rev. by St. Jones].- New York : Oxford University Press Inc. - 2042 pp.

\section{Надійшла до редакції 28.05.2019}

